Original scientific paper

\title{
ICT in Higher Education: Teachers' Experiences, Implementation and Adaptations
}

\author{
Andrea Miljko \\ Faculty of Humanities and Social Sciences, University of Mostar \\ Matice hrvatske b.b., Mostar, Bosnia and Herzegovina \\ andreaivankovic@gmail.com \\ Mateo Jurčić \\ Faculty of Humanities and Social Sciences, University of Mostar \\ Matice hrvatske b.b., Mostar, Bosnia and Herzegovina \\ mateo.jurcic@gmail.com \\ Tonćo Marušić \\ Faculty of Science and Education, University of Mostar \\ Matice hrvatske b.b., Mostar, Bosnia and Herzegovina \\ tonco.marusic@gmail.com
}

\begin{abstract}
Summary
Every aspect of human life is evolving so fast and with great quality. Nowadays, education has become more complex due to the enormous social change and a new view in the field of pedagogy. We live in the age of information and communication technology (ICT), and we cannot allow to ignore it in the education business management. The use of ICTs has great potential in teachers' preparation to deal with various challenges and responsibilities they have to fulfill in their educational environment. Thanks to fast-growing development of ICT in past decades, the topic of ICT integration in education is being intensively discussed at different levels. Considering this, teachers' ICT competences should play an important role, but the approach to ICT competences assessment - in general as in cases of teachers' profession - rarely exists. The presented article focuses on teachers' experiences, implementation and adaptations of ICT in higher educations. The research was conducted on the Faculty of Humanities and Social Sciences at the University of Mostar where it was determined the frequency of ICT use and the subjective evaluation of teachers' ICT understanding and their level of ICT literacy. Descriptive parameters of test variables as well as frequencies and percentages are demonstrated in the statistical data analysis.
\end{abstract}

Key words: ICT, teacher, higher education, ICT literacy 


\section{Introduction}

In the time of information and communication technologies the computer takes an important educational and scientific role. The influence of computers can be positive and negative, depending on the needs and ways of using the computer. In both cases, those impacts are rarely simple and direct and usually affected by many social and other factors.

In the past, education was highly elitist, but the era of information and communication technologies and the flexibility of using these technologies have enabled the participation of many students in the educational process. The technology education standards are extremely important for improving the quality of the educational process.

One of the basic requirements for education in this era of information explosion is to prepare learners for participation in a networked information society. This basic requirements can be available only when teachers are very aware of ICT [2].

\section{Theoretical background}

Teachers who wish to update and upgrade their teaching and learning designs using new learning technologies have some difficult issues to confront. Whether they work in schools, colleges, or universities, the incorporation of new technologies into their teaching requires them to acquire a very different approach to teaching and learning [9].

We live in the age of information and communication technology, and we cannot allow to ignore it in management of education business. The use of ICTs has great potential in teachers' preparation to deal with various challenges and responsibilities they have to fulfill in their educational environment. Therefore, many recent research studies on this subject show that many institutions do not manage to integrate technologies into the existing context. The teaching staff, although they have enough skills and they are innovative and they easily overcome obstacles, have not integrated technology as the means of learning and teaching [4]. Furthermore, [4] highlights the continuous problems in getting the teaching staff to acquire ICT and the need for further researches about how ICT can improve education.

Successful implementation of technology in education requires teacher's support and a positive attitude to a great extent. If the teachers feel that the ICT integration in teaching learning is not fulfilling their and their student's demands, then they will be somehow reluctant in using technology in teaching [7].

The main obstacle for using ICT among teaching staff, stated in [3], can be the following:

- The lack of self-confidence;

- The lack of competency;

- Resistance to change and negative attitudes. 
Nowadays teachers' ICT competence is considered to be a part of their professional competence, which is not a strictly defined area (i.e. containing e.g. only technical knowledge and skills related to the use of ICT in education), but an area which is coherent and consequent with other areas of teacher's professional competence (subject, pedagogical, didactic and psycho-didactic, diagnostic and intervention and others). The core of ICT lies in the interconnection of ICT with teacher's educational activity [8].

There are many complex factors that determine how university teachers employ ICT to change their teaching practices and/or the learning practices of their students. Evidence from studies into how ICT can enhance or transform educational processes states only one influence upon teachers [6]. Some others, often more pervasive, include:

- Individual differences in teachers' attitudes to the adoption of innovations;

- Individual differences in teachers' conceptions of and approaches to teaching;

- The established departmental / faculty / institutional ethos and ways of working; and

- Competing demands of discipline-based research and administration [6].

ICT presents an entirely new learning environment for students, requiring a different skill set to be successful. ICT is changing teaching and learning processes by adding elements of vitality to learning environments including virtual environments for the purpose. ICT is a potentially powerful tool for offering educational opportunities. It is difficult and maybe even impossible to imagine future learning environments that are not supported by ICT [10] in one way or another. The implementation of ICT by the teaching staff can have multiple benefits which can increase if the students are allowed to use ICT in the process of learning. Students can become more ICT literate if the teaching staff use ICT in their process of teaching. According to the analysis of literature, ICT competencies needed from teaching staff who work in a technologically enriched environment are:

- Recognition every single problem faced by students during the process of learning;

- Careful consideration of the choice regarding the use of media;

- Verification of given information;

- Development of effective search techniques and the ability to effectively do research on the computer;

- The ability to use standard software confidently and competently;

- The ability to make wise and critical decisions based on found information.

The majority of the teaching staff believes that the usage of technologies is important for the education. However, they lack the confidence and understanding 
during the process of integration. Further on, they should have skills and competencies needed for designing, delivering and the assessment because „successful integration of technology requires not only the knowledge of the technology and its potential use but also the skill to plan and execute a good lesson (of which the technology is only a part). When technology usage is aligned with the instructional goal, where technology is integral to teaching, successful integration might be succeeded" [4].

The use of new technologies in education implies new teacher roles, new pedagogies and new approaches to teacher's education. The successful integration of ICT into the classroom will depend on the ability of teachers to structure the learning environment in new ways, to merge new technology with a new pedagogy, to develop socially active classrooms, encouraging co-operative interaction, collaborative learning and group work. This requires a different set of classroom management skills [13].

Recent research on teachers' use of ICT in education shows a concern for the difficulties teachers face when trying to use ICT in their daily educational practices. One way to frame these difficulties concerns the many and varying ways in which ICT can be used [12].

The ICT knowledge and skills needed by teachers are never permanent and learning must be continual. Although new recruits to the profession will have live with a variety of ICT applications, even they need to engage in constant professional learning both about the technology and its pedagogical applications [1].

Successful integration of ICT in teaching and learning process is highly dependent on the preparation and attitudes of teachers. Undeniably that there are ICT tools available and easily accessible by teachers but even with the existence of these tools, teachers still failed to fully utilize ICT into their lessons. And, if they did utilize these tools, most employed the use of ICT in teaching language skills and even fewer studies paid attention to teachers' attitudes in using ICT in literature lessons. Teachers are one of the factors that determine the development and innovation in public education because they are the people who use ICT investment for the development of education. [11]

UNESCO's Framework emphasizes that it is not enough for teachers to have ICT competencies and be able to teach them to their students. Teachers need to be able to help the students become collaborative, problem-solving, creative learners through using ICT so they will be effective citizens and members of the workforce. [13] In order to have these competencies, the teaching stuff need to acuire a high level of ICT literacy.

ICT literacy has become an important prerequisite in the socialization and professional caree. Therefore, education as an important social factor plays a key role in ICT literacy. Basic ICT knowledge and skills contantly need to be updated in order to follow the fast development of ICT. 
A. Miljko, M. Jurčić, T. Marušić, ICT in higher education: Teachers' experiences ...

The purpose of this paper is to investigate teachers' experiences and views on ICT in higher education and the ICT literacy which is presented in the next chapters.

\section{Research questions}

In order to achieve the aims of the study, the following research questions were formulated:

- Do teachers use educational software for teaching purposes?

- Do teachers believe that the quality of scientific research work is increased by using computer technology?

- Do teachers believe that ICT literacy plays a key role in the educational process?

- Do teachers believe that they are ICT literate and in what measure?

\section{Research method}

The research was conducted among 65 teachers of the Faculty of Humanities and Social Sciences, University of Mostar. The research was carried out among 44 women $(64.69 \%)$ and 21 men (32.31\%). Among the tested sample, 22 (34.92\%) belong to the scientific field of social sciences and $41(65,08 \%)$ to humanities. ${ }^{1}$ As for the scientific-teaching titles, 53.85\% ( $\left.=35\right)$ are research assistants or senior research assistants, $32.31 \%(\mathrm{~N}=21)$ are assistant professors, $10.77 \%(\mathrm{~N}=7)$ are associate professors and $3.08 \%(\mathrm{~N}=2)$ are full professors.

The research was conducted through a questionnaire consisted of two parts: the first part of analysis refered to the frequency of computer use as well as the subjective evaluation of computer understanding by the teaching stuff. The second part was a test with 15 questions written in order to establish the level of ICT literacy.

Teachers come across different tools, softwares, terms and symbols while using ICT every day for different purposes. Therefore, the questions on the test were written to determine whether the subjects knew the things they use (e.g. do they know how the computer works, what is an operating system; what is a web browser).

The questionnaire was based on empirical insight of the teaching process conducted on the Faculty of Humanities and Social Studies of the University of Mostar.

Descriptive parameters, as well as frequencies and percentages, of researched variables were shown in the statistical data analysis.

The results of the ICT literacy test were given by a very simple linear compination of correct answers.

\footnotetext{
${ }^{1}$ Two subjects did not indicate their science field
} 
Spearman's rank correlation coefficient was used to test the correlation of ICT literacy and some habits of computer use. The differences in the level of ICT literacy between the teaching stuff and students, teachers of different fields and teaching and research positions were tested by the Chi-square test and/or a nonparametric test for testing differences between two/three independent groups. The results were interpreted on the significance level of $5 \%$.

The computer program STATISTICA (data analysis software system), version 7 was used for the statistical analysis.

\section{Findings and discussion}

A. Computer usage frequency and the understanding of computers efficacy Table 1 shows the computer usage frequency as well as the self-evaluation of their understanding of computers efficacy.

Table 1: Computer usage frequency and the understanding of computers efficacy

\begin{tabular}{|c|c|c|c|c|}
\hline No. & Question & Given answers & & \\
\hline & & & $\mathrm{f}$ & 62 \\
\hline 1 & Do you use computer technologies in & Yes & $\%$ & 96.87 \\
\hline 1. & your class? & No & $\mathrm{f}$ & 2 \\
\hline & & No & $\%$ & 3.13 \\
\hline & & Parelve & $\mathrm{f}$ & 3 \\
\hline & & Rarely & $\%$ & 4.76 \\
\hline & & & $f$ & 4 \\
\hline 2 & If you do circle hour often vou use it. & Sometımes & $\%$ & 6.35 \\
\hline 2. & It you do, circle how orten you use it: & & $\mathrm{f}$ & 10 \\
\hline & & Often & $\%$ & 15.87 \\
\hline & & Vervoften & $\mathrm{f}$ & 46 \\
\hline & & Very often & $\%$ & 73.01 \\
\hline & & & $\mathrm{f}$ & 43 \\
\hline & & More than 3 hours a day & $\%$ & 66.15 \\
\hline & & 22 boume dou & $\mathrm{f}$ & 14 \\
\hline 3 & How often do you use the computer? & 2-3 nours a day & $\%$ & 21.54 \\
\hline 3. & & $1-2$ hours a day & $\mathrm{f}$ & 7 \\
\hline & & $1-2$ hours a day & $\%$ & 10.77 \\
\hline & & $0-1$ bours a dav & $f$ & 1 \\
\hline & & $0-1$ hours a day & $\%$ & 1.54 \\
\hline & & Search the Internet & $\mathrm{f}$ & 40 \\
\hline & & Search the Internet & $\%$ & 61.54 \\
\hline & & Writing and creating different & $\mathrm{f}$ & 57 \\
\hline & & documents & $\%$ & 87.69 \\
\hline 4. & What do you use your computer for in & Communication with students & $f$ & 49 \\
\hline 4. & class? & communication witn students & $\%$ & 75.38 \\
\hline & & Make a presentation & $\mathrm{f}$ & 6 \\
\hline & & Make a presentation & $\%$ & 9.23 \\
\hline & & Paner presentations & $\mathrm{f}$ & 1 \\
\hline & & Paper presentations & $\%$ & 1.54 \\
\hline
\end{tabular}


A. Miljko, M. Jurčić, T. Marušić, ICT in higher education: Teachers' experiences ...

\begin{tabular}{|c|c|c|c|c|}
\hline No. & Question & \multirow{3}{*}{$\begin{array}{l}\text { Given answers } \\
\text { Work in programs specified } \\
\text { for certain college subjects }\end{array}$} & \multicolumn{2}{|c|}{ Results } \\
\hline & & & $f$ & 1 \\
\hline & & & $\%$ & 1.54 \\
\hline & & \multirow{2}{*}{ Preparing the lecture } & $\mathrm{f}$ & 2 \\
\hline & & & $\%$ & 3.08 \\
\hline & & \multirow{2}{*}{$\begin{array}{l}\text { Improving the class through } \\
\text { quality control }\end{array}$} & $\mathrm{f}$ & 1 \\
\hline & & & $\%$ & 1.54 \\
\hline & & \multirow{2}{*}{ Correcting papers } & $f$ & 1 \\
\hline & & & $\%$ & 1.54 \\
\hline & & \multirow{2}{*}{ Translation } & $\mathrm{f}$ & 1 \\
\hline & & & $\%$ & 1.54 \\
\hline & & \multirow{2}{*}{ Reading books } & $f$ & 1 \\
\hline & & & $\%$ & 1.54 \\
\hline & & \multirow{2}{*}{ Social media } & $f$ & 1 \\
\hline & & & $\%$ & 1.54 \\
\hline \multirow{4}{*}{5.} & \multirow{4}{*}{$\begin{array}{l}\text { Do you use any educational software for } \\
\text { your class needs? }\end{array}$} & \multirow{2}{*}{ Yes } & $\mathrm{f}$ & 12 \\
\hline & & & $\%$ & 19.35 \\
\hline & & \multirow{2}{*}{ No } & f & 50 \\
\hline & & & $\%$ & 80.65 \\
\hline \multirow{20}{*}{6.} & \multirow{20}{*}{ If you do, write which ones: ${ }^{2}$} & \multirow{2}{*}{ Merlin } & $\mathrm{f}$ & 3 \\
\hline & & & $\%$ & 27.27 \\
\hline & & \multirow{2}{*}{ Moodle } & $\mathrm{f}$ & 2 \\
\hline & & & $\%$ & 18.18 \\
\hline & & \multirow{2}{*}{ Power Point } & $\mathrm{f}$ & 4 \\
\hline & & & $\%$ & 36.36 \\
\hline & & \multirow{2}{*}{ Ephorus } & $f$ & 1 \\
\hline & & & $\%$ & 9.09 \\
\hline & & \multirow{2}{*}{ Pdf } & $f$ & 1 \\
\hline & & & $\%$ & 9,09 \\
\hline & & \multirow{2}{*}{$\begin{array}{l}\text { VLC } \\
\text { player }\end{array}$} & $f$ & 1 \\
\hline & & & $\%$ & 9,09 \\
\hline & & \multirow{2}{*}{ Hrčak } & $\mathrm{f}$ & 1 \\
\hline & & & $\%$ & 9,09 \\
\hline & & \multirow{2}{*}{ Busyteacher } & $\mathrm{f}$ & 1 \\
\hline & & & $\%$ & 9,09 \\
\hline & & \multirow{2}{*}{ Englishtips } & $f$ & 1 \\
\hline & & & $\%$ & 9,09 \\
\hline & & thefreedictionary com & $\mathrm{f}$ & 1 \\
\hline & & & $\%$ & 9,09 \\
\hline & & 1 (not enough) & $\mathrm{f}$ & 1 \\
\hline & & & $\%$ & 1.54 \\
\hline & & 2 (anourh) & $\mathrm{f}$ & 11 \\
\hline 7 & Assess how well you understand & 2 (enough) & $\%$ & 16.92 \\
\hline & computers and computer technologies: & 3 (well) & $\mathrm{f}$ & 30 \\
\hline & & & $\%$ & 46.15 \\
\hline & & 4 (yorn woll) & $\mathrm{f}$ & 17 \\
\hline & & 4 (very well) & $\%$ & 26.15 \\
\hline
\end{tabular}

${ }^{2}$ Question no. 6 was an open-ended question. Their answers are represented in the table. 
INFuture2017: Integrating ICT in Society

\begin{tabular}{|c|c|c|c|c|}
\hline No. & Question & Given answers & \multicolumn{2}{|c|}{ Results } \\
\hline & & \multirow[b]{2}{*}{5 (excellent) } & $f$ & 6 \\
\hline & & & $\%$ & 9.23 \\
\hline \multirow{4}{*}{8.} & \multirow{4}{*}{$\begin{array}{l}\text { Does the use of computers imply the use } \\
\text { of Internet? }\end{array}$} & \multirow{2}{*}{ Yes } & $\mathrm{f}$ & 5 \\
\hline & & & $\%$ & 7.81 \\
\hline & & \multirow[b]{2}{*}{ No } & $f$ & 59 \\
\hline & & & $\%$ & 92.19 \\
\hline \multirow{8}{*}{9.} & \multirow{8}{*}{$\begin{array}{l}\text { Do you think that the knowing computers } \\
\text { and computer technologies is highly } \\
\text { essential in our everyday life? }\end{array}$} & \multirow{2}{*}{ Absolutely not } & $f$ & 1 \\
\hline & & & $\%$ & 1.56 \\
\hline & & \multirow{2}{*}{ Partly } & $f$ & 2 \\
\hline & & & $\%$ & 3.13 \\
\hline & & \multirow{2}{*}{ Moderately } & $\mathrm{f}$ & 8 \\
\hline & & & $\%$ & 12.50 \\
\hline & & \multirow{2}{*}{ Very } & $f$ & 53 \\
\hline & & & $\%$ & 82.81 \\
\hline \multirow{8}{*}{10.} & \multirow{8}{*}{$\begin{array}{l}\text { Do you think that the quality of scientific } \\
\text { work increases with the use of computer } \\
\text { technologies? }\end{array}$} & \multirow{2}{*}{ Absolutely not } & $\mathrm{f}$ & 3 \\
\hline & & & $\%$ & 4.69 \\
\hline & & \multirow{2}{*}{ Partly } & $\mathrm{f}$ & 1 \\
\hline & & & $\%$ & 1.56 \\
\hline & & \multirow{2}{*}{ Moderately } & $f$ & 30 \\
\hline & & & $\%$ & 46.87 \\
\hline & & \multirow{2}{*}{ Very } & $\mathrm{f}$ & 30 \\
\hline & & & $\%$ & 46.87 \\
\hline \multirow{8}{*}{11.} & \multirow{8}{*}{$\begin{array}{l}\text { Do you think that ICT literacy plays a key } \\
\text { role in the educational process? }\end{array}$} & \multirow{2}{*}{ Absolutely not } & $f$ & 1 \\
\hline & & & $\%$ & 1.54 \\
\hline & & \multirow{2}{*}{ Partly } & $\mathrm{f}$ & 1 \\
\hline & & & $\%$ & 1.54 \\
\hline & & \multirow{2}{*}{ Moderately } & $f$ & 32 \\
\hline & & & $\%$ & 49.23 \\
\hline & & \multirow{2}{*}{ Very } & $f$ & 31 \\
\hline & & & $\%$ & 47.69 \\
\hline \multirow{8}{*}{12.} & & Absolutely not & $\mathrm{f}$ & 2 \\
\hline & & & $\%$ & 3.08 \\
\hline & & & $\mathrm{f}$ & 4 \\
\hline & Do you think that the use of computer & Partly & $\%$ & 6.15 \\
\hline & $\begin{array}{l}\text { moster new units more easily? } \\
\text { masto }\end{array}$ & Moderately & $f$ & 47 \\
\hline & & Moderately & $\%$ & 72.31 \\
\hline & & Verv & $f$ & 12 \\
\hline & & very & $\%$ & 18.46 \\
\hline & & Yes & f & 55 \\
\hline 13 & Do you think you are ICT literate? & Yes & $\%$ & 85.94 \\
\hline 10 . & Do you tmink you are ic I inerale? & No & $\mathrm{f}$ & 9 \\
\hline & & INO & $\%$ & 14.06 \\
\hline
\end{tabular}

In the question "Do you use computer technologies in your class?" $96.87 \%$ of the subjects stated that they do use the computer, and only $3.13 \%$ that they do not use computer technologies. $73.01 \%$ of the teaching staff uses computers in class very often, $15.87 \%$ often, $6.35 \%$ sometimes and $4.76 \%$ rarely. 
The research showed that $66.15 \%$ of the subjects used the computer more than three hours a day, $21.54 \%$ two to three hours a day, $10.77 \%$ one to two hours a day and $1.54 \%$ one hour or even less a day.

In the question "What do you use your computer for in class?" the majority of them $87.69 \%$ stated for writing and creating different documents, and the smallest percentage for paper presentations, correcting papers, work in programs specified for certain college subjects, preparing the lecture, Improving the class through quality control, translation, reading books or for social networks. ${ }^{3}$ Further research has shown that only $19.35 \%$ of the teaching staff uses some of the educational software for class needs, while $80.65 \%$ do not use any software (Figure 1). Among those who use educational software, 27.27\% named Merlin software, $36.36 \%$ Power Point, $18.18 \%$ Moodle software and $9.09 \%$ the use of Ephorus, Pdf, VLC player, Hrčak, Busyteacher, Englishtips or the freedictionary.com which they think are educational software.

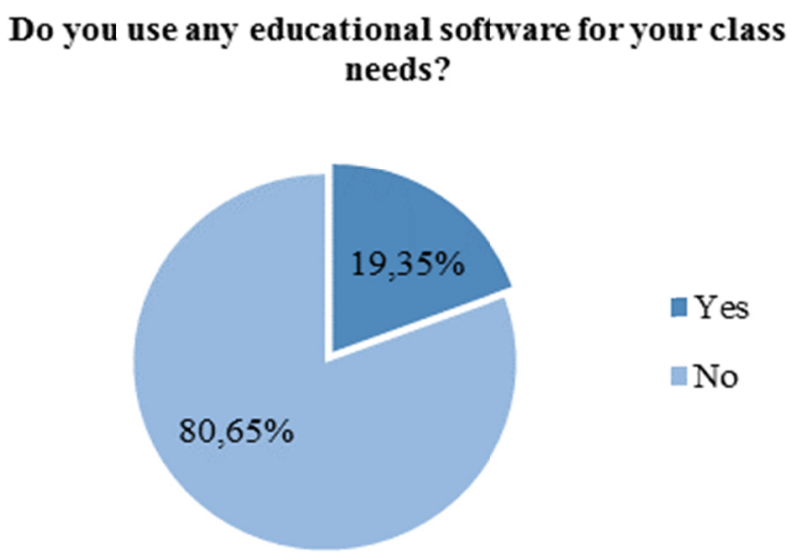

Figure 1. Question "Do you use any educational software for your class needs?"

As for self-evaluation of their understanding of computers and computers technology efficacy, the highest percentage believe that they understand well $(46.15 \%)$ or very well $(26.15 \%)$ computers and computer technologies software (Figure 2). Also, $92.19 \%$ of them do not think that the use of computers necessarily implies the use of Internet.

In the question "Assess how well you understand computers and computer technologies" the scientific-teaching staff both from the humanistic and social studies equally believe they understand computers and computer technologies The majority of subjects, $82.81 \%$, believes that knowing computers and computer technologies is highly essential in our everyday life. Also, the highest

${ }^{3}$ The subjects were given the opportunity to give multiple answers. 
INFuture2017: Integrating ICT in Society

number highlights that the quality of scientific work has significantly increased with the use of computer technologies.

The question "Do you think that ICT literacy plays a key role in the educational process?" shows that only $1.54 \%$ answered absolutely not or partly, $49.23 \%$ moderately, and $47.69 \%$ (Figure 3).

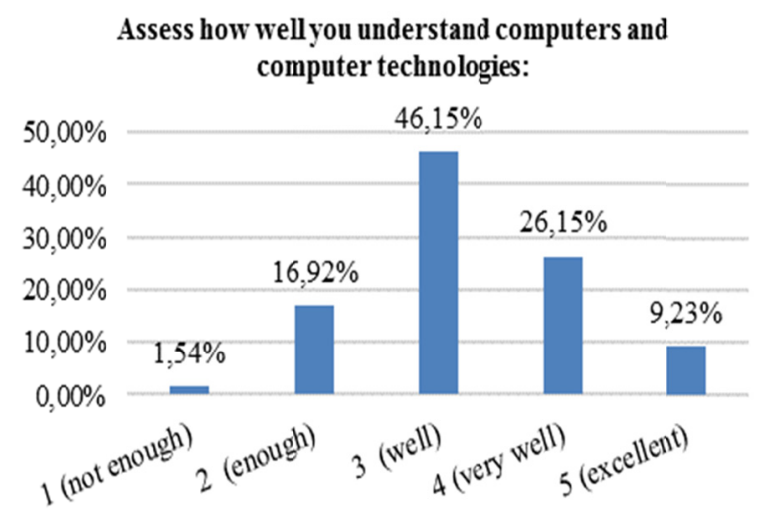

Figure 2. Question "Assess how well you understand computers and computer technologies

\section{Do you think that ICT literacy plays a key role in the educational process?}

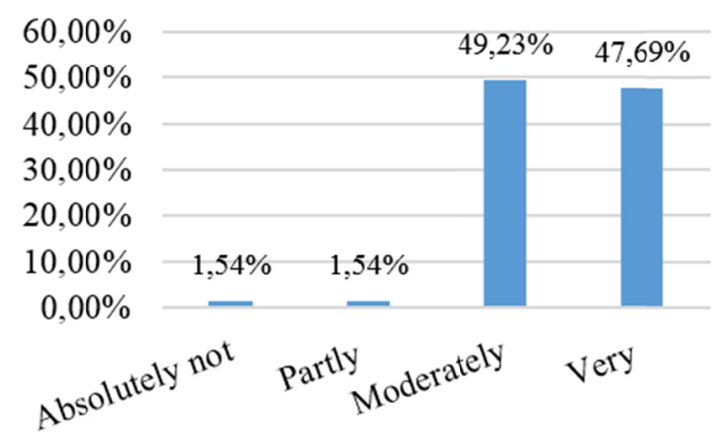

Figure 3. The question "Do you think that ICT literacy plays a key role in the educational process?"

The majority of the teaching staff thinks that the use of computer technologies in class moderately helps students master new units more easily.

The last question referred to the self-evaluation of ICT literacy in which $85.94 \%$ answered that they thought they are ICT literate and $14.06 \%$ stated contrary. 
A. Miljko, M. Jurčić, T. Marušić, ICT in higher education: Teachers' experiences ...

\section{B. Results from the Knowledge test of teaching stuff's ICT literacy}

The level of teaching staff's ICT literacy was tested by objective measurement.

The questionnaire was taken from the paper "ICT Literacy among the Students of the Faculty of Philosophy, University of Mostar" in which all the same quastions were given to students. In the quoted paper students achieved average results. [5]

This research wanted to show the level of teaching staff's ICT literacy.

According to data analysis the percentage of correct answers on the Test of ICT literacy varies from $37.10 \%$ to $98.41 \%$ (Table 2, Figure 4). The lowest percentage, only $37.10 \%$ of all the subjects, knew which operating system was produced in 2011 by Microsoft, while $98.41 \%$ knew which function on the computer reruns the system and the constituent part of the symbol @.

Table 2. Results from the Knowledge test of teaching stuff's ICT literacy

\begin{tabular}{|c|c|c|c|c|}
\hline \multirow{2}{*}{ No. } & \multirow{2}{*}{ Question } & \multicolumn{3}{|c|}{ Answers } \\
\hline & & f $/ \%$ & \begin{tabular}{l|l} 
Correct & \\
\end{tabular} & Incorrect \\
\hline \multirow{2}{*}{1.} & \multirow{2}{*}{ On which digits is the computer world built? } & $\mathrm{f}$ & 51 & 22 \\
\hline & & $\%$ & 82.26 & 17.74 \\
\hline \multirow{2}{*}{2.} & \multirow{2}{*}{ What of the listed represents an operating system? } & $\mathrm{f}$ & 56 & \\
\hline & & $\%$ & 88.89 & 11.11 \\
\hline \multirow{2}{*}{3.} & \multirow{2}{*}{ What is Facebook? } & $\mathrm{f}$ & 61 & 2 \\
\hline & & $\%$ & 96.83 & 3.17 \\
\hline \multirow{2}{*}{4.} & \multirow{2}{*}{ What is http? } & $\mathrm{f}$ & 30 & 33 \\
\hline & & $\%$ & 47.62 & 52.38 \\
\hline \multirow{2}{*}{5.} & \multirow{2}{*}{ Whose founder was Steve Jobs? } & $\mathrm{f}$ & 58 & \\
\hline & & $\%$ & 92.06 & 7.94 \\
\hline \multirow{2}{*}{6.} & \multirow{2}{*}{$\begin{array}{l}\text { Which number in the picture represents the space bar } \\
\text { button? }\end{array}$} & $\mathrm{f}$ & 57 & \\
\hline & & $\%$ & 93.44 & 6.56 \\
\hline \multirow{2}{*}{7.} & \multirow{2}{*}{ Which shortcut means Cut? } & $\mathrm{f}$ & 42 & 18 \\
\hline & & $\%$ & 70.00 & 30.00 \\
\hline \multirow{2}{*}{8.} & \multirow{2}{*}{$\begin{array}{l}\text { What is the operating system produced by Microsoft in } \\
\text { the 2011. year? }\end{array}$} & $\mathrm{f}$ & 23 & 39 \\
\hline & & $\%$ & 37.10 & 62.90 \\
\hline \multirow{2}{*}{9.} & \multirow{2}{*}{ Which one of listed is an IP address? } & f & 53 & \\
\hline & & $\%$ & 86.89 & 13.11 \\
\hline \multirow{2}{*}{10.} & \multirow{2}{*}{ Which function on the computer reruns the computer? } & $\mathrm{f}$ & 62 & \\
\hline & & $\%$ & 98.41 & 1.59 \\
\hline \multirow{2}{*}{11.} & \multirow{2}{*}{ @ sign is an integral part of: } & $\mathrm{f}$ & 62 & \\
\hline & & $\%$ & 98.41 & 1.59 \\
\hline \multirow{2}{*}{12.} & \multirow{2}{*}{ Which one of the listed represents a wireless network? } & f & 56 & \\
\hline & & $\%$ & 88.89 & 11.11 \\
\hline \multirow{2}{*}{13.} & \multirow{2}{*}{ What does the shortcut PC mean? } & f & 59 & \\
\hline & & $\%$ & 93.65 & 6.35 \\
\hline \multirow{2}{*}{14.} & \multirow{2}{*}{ What program is used for website browsing? } & $\mathrm{f}$ & 32 & 31 \\
\hline & & $\%$ & 50.79 & 49.21 \\
\hline 15 & What file extension makes only an image file? & $\mathrm{f}$ & 61 & 2 \\
\hline 15. & What tile extension makes only an image tile? & $\%$ & 96.83 & 3.17 \\
\hline
\end{tabular}




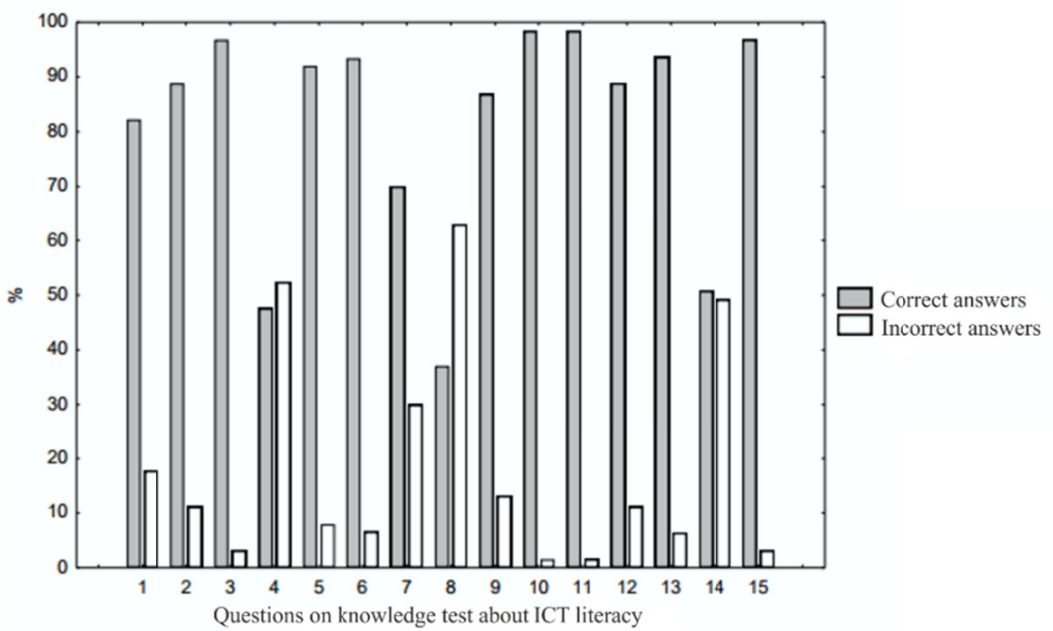

Figure 4. The presentation of results from the knowledge test of teaching stuff's ICT literacy

The distribution of results on the Test of ICT literacy is negatively assimetrical which means that most teaching staff have accomplished extraordinary results. (Figure 5). According to the median value, there are 13.33 out of 15 correct answers. The median value of correct answers is $88.89 \%$, and of incorrect $11.11 \%$. The distribution of test results raises a question whether the test results are the real reflection of ICT literacy. This distribution shows that the test is insufficiently accurate: or the teaching staff is extraordinary literate or the test is too easy.

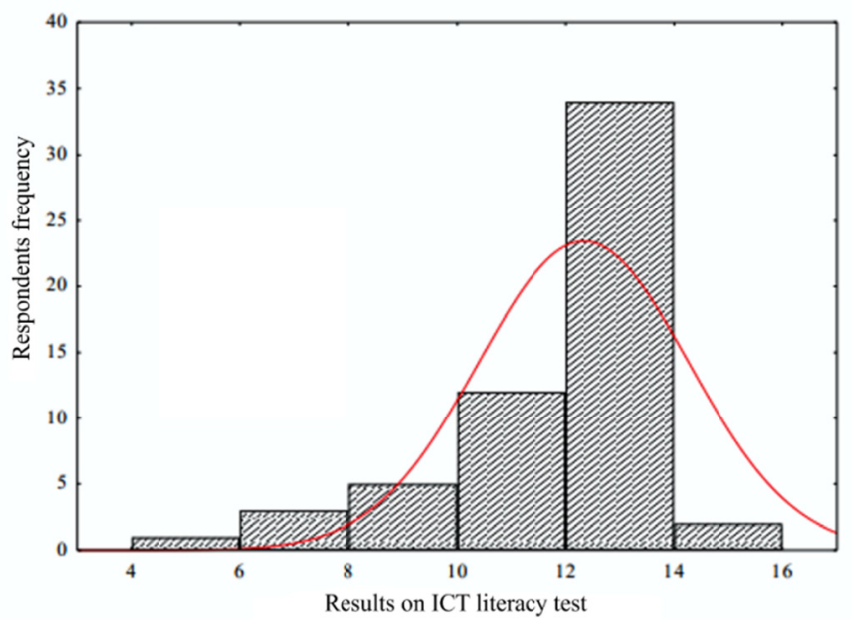

Figure 5. The distribution of results of the ICT literacy knowledge test of teaching stuff from the Faculty of Humanities and Social Studies of the University of Mostar 
The data analysis showed the correlation between ICT literacy and habits of computer use, as well as the self-evaluation of computer knowledge and ICT literacy (Table 3). A significant positive statistical link was established between the subjective evaluaton of computers and the results of the ICT literacy test. The given correlation demonstrates that the subjects with better insight in computers have accomplished better results on the test. Apart the positive correlation, a negative correlation between the subjective evalution of ICT literacy and the objective level of ICT literacy has been established.

There is a tendency among some teaching stuff with higher results on the ICT literacy test to poorly assess their own knowledge and and vice versa, subjects with lower results, evaluate themselves more ICT literate. These results can be indirectly explained in the way that people with lower self-evaluation are more pron to perfectionism and therefore are more self-critical and doubtful.

Table 3. The correlation between ICT literacy and the habits od computer use and the self-evaluation of computer and ICT literacy knowledge.

\begin{tabular}{|l|c|}
\hline Variables & ICT literacy \\
\hline Daily use of computers & 0.144 \\
\hline Knowledge self-evaluation of computers and computer technology & $0.367{ }^{*}$ \\
\hline Self-evaluation of ICT literacy & $-0.336^{*}$ \\
\hline
\end{tabular}

\section{Conclusion}

Thanks to fast-growing development of ICT in past decades, the topic of ICT integration in education is being intensively discussed at different levels. Considering this, teachers' ICT competences should play an important role, but the approach to ICT competences assessment - in general as in cases of teachers' profession - rarely exists.

Technologies have a great potential for improving different aspects in everyday life, including education. Nowadays, technology plays a key role in the effective achievement of class aims and tasks in the educational system. Computers and computer technologies are considered to be efficient teaching tools. In an academic world students expect a positive learning atmosphere based on ICT. The teaching staff should provide ICT literacy skills in an environment like that. It could be said that ICT is an essential condition for higher education.

Our research has shown that almost all the teachers use computer technologies for their class needs. And that they mostly use the computer more than three hours a day.

The subjects mostly use computers for writing and creating different documents. However, this research has shown that the teachers do not use any educational software and that they do not even know what educational software is, because in their answers they use different programs and web pages that are not part of any educational software.

According to the self-evaluation of their understanding of computers and computers technology efficacy the highest percentage thinks that they understand 
computers and computer technologies. Subjects believe that computers and computer technologies are highly essential in our everyday life, and that their use significantly increases the quality of scientific work. Furthermore, subjects also believe they are ICT literate.

The ICT literacy test has shown great results about the teaching stuff's knowleddge, i.e. it has shown that they are ICT literate.

The ICT literacy focuses on process knowledge, critical thinking and problem solving which can be found among information in a digital environment. Altough the skills which are a part of the ICT literacy are acquired through education, they can be extended beyond the academic life to real life which enables us to function in an informational and technological enriched society. The given components are highly required in institutions based on the development of knowledge, skills, understanding attittudes and trends which ensure students a successful life and work in the $21^{\text {st }}$ century.

\section{References}

[1] Albion, Peter; Knezek, Don; Adubra, Edem. (2011). TWG3: Teacher Professional Development. EDUsummIT 2011. Paris, France: UNESCO.

[2] Angadi, Gavisiddappa R. Teachers' Attitude towards Information and Communication Technology (ICT). // International Journal of Education and Psychological Research (IJEPR). 3 (2014), 1

[3] Bingimlas, Bingimlas. Barriers to the Successful Integration of ICT in Teaching and Learning: A Review of Literature. // Eurosia Journal of Matematics, Science and Technology Education. 5 (2009); 235-245

[4] Gülbahar, Yasemin. ICT Usage In Higher Education: A Case Study on Preservice Teachers and Instructors. // The Turkish Online Journal of Educational Technology - TOJET. 7 (2008), 1

[5] Ivanković, Andrea; Špiranec, Sonja; Miljko, Dražan. ICT Literacy among Students of the Faculty of Philosophy, University of Mostar. // Procedia - Social and Behavioral Sciences. 93 (2013); 684-688

[6] Kirkwood, Adrian. ICT in higher education: policy perspectives // ICT Leadership in Higher Education. India: Hyderabad. (2013); 36-43

[7] Kler, Shikha. ICT Integration in Teaching and Learning: Empowerment of Education with Technology.// Issues and Ideas in Education. 2 (2014), 2; 255-271

[8] Kubrický, Jan; Č́stková, Pavlina. Teachers ICT Competence and Their Structure as A Means of Developing Inquiry-Based Education. // Procedia - Social and Behavioral Sciences. 186 (2015); 882-885

[9] Laurillard, Diana. Supporting Teacher Development of Competencies in the Use of Learning Technologies. // ICT in teacher education: policy, open educational resources and partnership, IITE / UNESCO. Moscow; UNESCO, 2010; 63-74

[10] Noor-Ul-Amin, Syed. An Effective use of ICT for Education and Learning by Drawing on Worldwide Knowledge, Research and Experience: ICT as a change Agent for Education. // Scholarly Journal of Education. 2 (2013), 4; 38-48

[11] Shah Md., Parilah; ESL Teachers' Attitudes towards Using ICT in Literature Lessons.// International Journal of English Language Education. 3 (2015), 1; 201-2018

[12] Talebiana, Sogol; Mohammadia, Hamid Movahed; Rezvanfar, Ahmad. Information and communication technology (ICT) in higher education: advantages, disadvantages, conveniences and limitations of applying e-learning to agricultural students in Iran. // Procedia Social and Behavioral Sciences. 152 (2014); 300-305

[13] UNESCO. ICT Competency Framework for Teachers. Paris: UNESCO, 2011. 